\section{Dilema brasileiro e entretenimento na cobertura da violência no Rio}

Maurício da SILVA DUARTE

\section{Resumo}

Busca-se refletir sobre continuidades e rupturas nas representações sociais sobre a violência no Rio gestadas ou reforçadas no período militar e na redemocratização, cotejando com as análises realizadas num trabalho anterior sobre a interpretação da criminalidade violenta pelos jornais cariocas a partir da metáfora da guerra. As continuidades dizem respeito à presença nos jornais do híbrido cultural brasileiro, a tensão entre os princípios igualitários e universais que regem a vida democrática e a naturalização das desigualdades e hierarquias sociais. As rupturas remetem à presença do entretenimento nesses relatos noticiosos. A hibridização ideológica desses elementos naturalizados e persuasivos tem resultado na reafirmação do dilema brasileiro pelas redações dos jornais.

Palavras-chave: violência; jornalismo; cidadania; direitos humanos; análise de discurso.

\section{Un dilema brasileño y el entretenimiento en la cobertura de Prensa de la violencia en Río de Janeiro}

Resumen: Este artículo intenta pensar sobre las continuidades y rupturas en las representaciones sociales de la violencia en la ciudad de Río de Janeiro empezadas o reforzadas en el período militar 1964-1985 y en la Democracia posterior, en comparación con el análisis realizado en una investigación anterior sobre la interpretación de los delitos violentos por la Prensa de Río, hacia la metáfora de la guerra. Las continuidades hablan de la presencia en los periódicos del concepto de 'híbrido cultural brasileño', además de la tensión entre los principios igualitarios y universales de la vida democrática y la naturalización de las desigualdades y las jerarquías sociales.

1 Posdoutorando em Comunicação Social (UFRJ), doutor em Comunicação e Cultura (UFRJ), mestre em Sociologia (IUPERJ-SBI), graduado em Jornalismo (UFF) e em História (UFF). É professor titular do curso de Comunicação Social da Universidade Salgado de Oliveira (Universo) - Campus Niterói.
Las rupturas se refieren a la presencia de entretenimiento en estos noticieros. La hibridación ideológica de estos elementos naturalizados y persuasivos ha provocado la reafirmación del dilema brasileño en las oficinas de los periódicos.

Palabras clave: violencia, Periodismo, ciudadania, derechos humanos, análisis del discurso.

O objetivo deste artigo é refletir sobre as formas com que a violência no Rio de Janeiro é representada e gerenciada nos jornais cariocas. As Ciências Sociais tiveram que dialogar, no período pós-abertura do regime militar, com representações sociais gestadas ou reforçadas ao longo do regime de 1964. A expectativa deste trabalho é propor que o olhar sobre essas representações sociais auxilie na compreensão do funcionamento ideológico dos textos noticiosos em pelo menos duas questões fundamentais, sobre as quais me debrucei em pesquisa anterior $^{2}$. A primeira é o papel condutor dos jornais na classificação da violência do Rio como uma guerra e a consequente imposição dessa metáfora como lógica de interpretação da política de segurança no Rio. A segunda, o uso do entretenimento como elemento persuasivo na construção do gênero "cobertura da violência" :

O tema "criminalidade urbana" passou a ser uma discussão ampla a partir da redemocratização, nos anos 1980, quando o aumento das estatísticas de crime gerou perplexidade entre intelectuais e também ampla reação moral nos jornais e na sociedade. Até então, a violência que se discutia em setores da comunidade política e na universidade era a da política revolucionária, do uso da força para viabilizar a revolução e derrotar o mecanismo autoritário de repressão. Naturalmente, a observância à lei e ordem somente pode ser cultivada em sociedades organizadas sob o estado democrático de direito. Não é de estranhar, portanto, que o imaginário social nas décadas de 1960 e 1970 valorizasse atitudes que desafiassem a ordem ditatorial, muitas vezes idealizando o personagem criminoso. A denúncia do autoritarismo estatal convivia com a percepção da transgressão como uma forma de protesto social, do crime como uma guerra civil sem ideologia e do bandido como um rebelde primitivo, ainda sem consciência política. Alguns jornais ainda reproduziam esse modelo interpretativo na abordagem de incêndios de ônibus em 2000, atribuindo esse tipo de violência a uma reação irracional da população, um protesto pré-político.

2 DUARTE, M. S. Cidadania obstruída: jornais cariocas e a construção discursiva da violência no Rio. Rio de Janeiro: ECO-UFRJ, 2003, mimeo. 
É o que se vê na notícia publicada no EXTRA (19/07/2001 - figura 1 do anexo), onde há sete fotos, seis das quais de incêndios de ônibus além do uso do trocadilho na manchete ("Revoltas incendeiam o Rio"), num conjunto de elementos persuasivos. Não há referências ao crime organizado. Ao contrário, a escolha vocabular "revoltas" como sujeito remete a uma ação anárquica e espontânea da população. Em O GLOBO (21/10/2000, p. 17, também figura 1), desloca-se para a primeira página da seção "Rio" a espetacularização da notícia. A depredação de ônibus é interpretada dentro da tradição de que os quebra-quebras seriam uma reação ao autoritarismo do Estado e à deterioração das condições de vida da população pobre. O título é publicitário, tem valor expressivo "alarmista", com forte apelo emocional, nominalizado (sem sujeito) e sem maiores informações: "Quebra-quebra no Centro". No subtítulo, o relato do fato aparece de forma mais informativa: "Moradores de favela fecham viaduto e depredam ônibus depois de ação da PM". O destaque é para o sujeito "moradores de favela", que, embora ligado a ações avaliadas negativamente, é atenuado por "depois da ação da PM", justificando a ação dos moradores de favela. Em contraposição, no jornal O DIA (18/06/2002, figura 1), uma nova interpretação estaria consolidada. A queima de ônibus era atribuída à "ousadia dos bandidos", em resposta à morte de um traficante. O GLOBO (22/06/2002, p. 12, figura 2), traria a manchete: "Violência pega carona nos ônibus". E o subtítulo: "Só neste ano, 66 veículos incendiados em conflitos, a maioria com participação do tráfico", com o uso anafórico para operar a inclusão dos fatos anteriores dentro da lógica do tráfico como responsável da ação, consolidando a nova interpretação ${ }^{3}$.

O crescimento das estatísticas da violência urbana nas décadas de 1980 e 1990 foi seguido pela maior ênfase na cobertura jornalística. Num livro em que defendia a interpretação do aumento dos assaltos e roubos nas cidades como uma "estratégia de sobrevivência por parte das classes dominadas", Ruben Oliven ${ }^{4}$ queixa-se da "dramatização da violência", que ele constata ter sido "alçada ao status de questão nacional" pela imprensa. Entre os problemas apontados na divulgação noticiosa seria o foco nos crimes dos pobres, a minimização do arbítrio policial e a omissão em relação a violências institucionais, como acidentes de trabalho, desnutrição infantil e miséria. Após mostrar surpresa com presença

$3 \mathrm{Um}$ aprofundamento analítico dessas e outras reportagens podem ser encontradas em DUARTE, M.S. op. cit., capítulo 8.

4 OLIVEN, Ruben George. Violência e cultura no Brasil. Petrópolis: Vozes, 1989, p. 14-25. de crimes comuns na pauta do Fantástico, da TV Globo, Oliven relaciona o processo de acumulação capitalista à violência também no campo e ironiza: "Seria altamente fantástico que um programa como o Fantástico começasse a tratar da violência no campo no Brasil”"5.

O arbítrio policial na gestão dos conflitos sociais urbanos é certamente uma linha de continuidade na política da ditadura militar, como sugerem estudos realizados nos anos 1990 sobre a crescente autonomização da polícia em relação ao Estado, as relações promíscuas entre as forças de segurança e a criminalidade e o flagrante desrespeito à ordem constitucional, inclusive com a repetição de chacinas patrocinadas por grupos policiais. Carvalho (1995, p. 56) define essa herança do regime militar como um afastamento, não apenas pela polícia, mas da sociedade em geral, do quadro normativo vigente. A recusa às instituições do autoritarismo teria como consequência a desmoralização da lei, o que contribuiu para "a proliferação de instituições informais e de fatos de violência imputáveis a agentes paraestatais, grupos políticos armados, contraventores e bandos criminosos, todos vivendo à margem da lei" ${ }^{\text {“ }}$ O fortalecimento organizacional do jogo do bicho seria um dos desdobramentos dessa generalização da tolerância com o desviante. Ao mesmo tempo que bicheiros assumiam controle político sobre comunidades onde mantinham seus negócios, processo que conheceu uma dimensão paramilitar, o jornal Pasquim os promovia à condição de benfeitores do mundo popular.

A criação do mais famoso grupo de extermínio da época tem a mesma lógica de descaso com a lei. Em agosto de 1964, o policial Milton Le Cocq é morto em tiroteio com o bandido Cara de Cavalo, que, dois meses depois, seria executado pela polícia com 60 balas no corpo. Um artigo de David Nasser, “Dez por Um”, inspiraria o nascimento da Escuderia Milton Le Cocq, quando o jornalista pediu a cabeça de dez bandidos para cada policial morto. Anos depois, o delegado Sérgio Fleury integraria a lista de policiais do esquadrão da morte, denunciada por uma pessoa ligada ao Esquadrão. No processo, o procurador da justiça Hélio Bicudo acusa o Esquadrão de acobertar o tráfico de drogas, exterminando quadrilhas em benefício de outras. Fleury é beneficiado por uma lei baixada em 1973, que mantinha em liberdade, mesmo depois de condenados, os réus primários de bons antecedentes até o julgamento do recurso em última instância. A lei foi batizada de Lei Fleury ${ }^{6}$.

5 Ibidem, p. 16.

6 A história, contada de forma mais detalhada, pode ser lida em NOSSO SÉCULO - 1960/1980, sob as ordens de Brasília, 2a parte. São Paulo: 
Outra representação social contestada por estudiosos no período pós-redemocratização associa de forma mecânica e monocausal a criminalidade à pobreza, uma opinião também generalizada no imaginário social. O modelo de realização conservadora e autoritária do desenvolvimento econômico e modernização industrial adotado pelo regime militar é a referência dessa representação social. A acelerada acumulação capitalista no Brasil foi conduzida pela reiteração do compromisso entre elites e oligarquias dominantes da cidade e do campo, radicalizada e tornada viável pela ditadura militar. Em menos de duas décadas, a população do campo migra em massa para as cidades, onde passam a viver em condições extremas de privação e exploração. O Brasil tornase uma nação urbana, em que apenas 30\% da população mantêm-se no campo, mas também um exemplo mundial de concentração de renda e exclusão das camadas subalternas (Soares, 2000). Os estudos sociológicos nos anos 1970, então, buscariam associar o padrão autoritário de desenvolvimento econômico aos conflitos urbanos no país, como forma de condenação do autoritarismo estatal.

O crime efetivamente cresceu em escala industrial no Rio de Janeiro e no país a partir da década de 1980, com a expansão do tráfico de drogas e armas de grande poderio ofensivo. Isso fez com que o noticiário sobre a violência transbordasse dos "seus tradicionais redutos nas editorias e jornais especializados em crimes e ganhasse destaque, de maneira generalizada, em todos os meios de comunicação" (Rondelli, 2000, p. 144). Também produziu questionamentos à associação automática com os indicadores macroeconômicos como referência analítica. Em 1987, um artigo de Edmundo Campos Coelho mostra, a partir de dados empíricas, que a criminalidade cresceu em 1986, com o Plano Cruzado, apesar da redução do número de brasileiros abaixo da linha da pobreza. Pesquisas de campo desenvolvidas por Paixão e Zaluar ${ }^{7}$ reforçariam a autonomia da análise sociológica sobre os indicadores macroeconômicos, com ênfase nos contextos institucional e cultural.

A repercussão da cobertura jornalística gera então debates intensos também em outras esferas e agências. Como assinala Rondelli (2000, p. 153) vários atores sociais produzem, então, discursos que convergem para

Abril Cultural, 1980, p.66-67.

7 PAIXÃO, A.L. "Crimes e criminosos em Belo Horizonte". In. BOSCHI (org.) Violência e cidade. Rio de Janeiro: Zahar, 1982. ZALUAR, Alba. A máquina e a revolta - organizações populares e o significado da pobreza. São Paulo: Brasiliense, 1985. Também: ZALUAR, Alba Cidadãos não vão ao Paraíso - juventude e política social. São Paulo: Editora Escuta; Campinas: Editora da Unicamp, 1994. os meios de comunicação, que os recontextualizam e reconfiguram segundo uma ordem narrativa própria. Lugar privilegiado de visibilidade dos diversos discursos, os meios de comunicação articulam e processam essas vozes de forma intertextual, num processo de negociação e produção de sentidos. Os novos consensos construídos a partir daí vão sedimentar algumas imagens e pressupostos sobre favela e violência. Valladares (2005, p. 20 e p. 148-152) mostra o compartilhamento desses sentidos e imagens, a partir dos relatos noticiosos sobre violência no Rio, o tráfico de drogas e criminalidade nas favelas e no entorno, a partir dos anos 1980. Ao mesmo tempo que a guerra nas favelas é transformada numa especificidade carioca, as reportagens estimulam o interesse dos estudiosos. A associação quase sistemática entre pobreza e criminalidade teria feito da favela sinônimo de espaço fora da lei, onde bandidos e policiais estão constantemente em luta. O medo dos habitantes da cidade formal em relação aos morros foi reforçado, acentuando a visão dualista, manifesta em formulações como "cidade partida" e "metáfora da guerra".

Essas representações alimentam o que a autora defende serem "dogmas" nas pesquisas acadêmicas. Apesar da abordagem sofisticada, do esforço epistemológico e compreensivo, a favela ali também se constitui de forma genérica num território singular, com cultura própria, sob controle do narcotráfico. A característica da favela seria ainda a identificação como o território urbano da pobreza, formando uma cidade ilegal dentro da cidade legal, com leis intramuros e códigos particulares. Abandonadas pelo poder público, as favelas seriam o símbolo da "cidade partida", da segregação socioespacial das grandes metrópoles brasileiras, em especial no Rio de Janeiro. As consequências seriam a redução do universo plural que constitui o universo das favelas a uma categoria única e homogênea, o que obscurece a sua diversidade, além da sedimentação da visão dualista da cidade, dividida entre favela e o asfalto, apesar da grande diversidade no modo de vida também em Ipanema ou Leblon e os bairros populares periféricos. Sem contar que há pobreza, arbítrio policial e tráfico de drogas em muitos outros bairros fora da favela.

A esse diagnóstico sobre as representações convergentes, deve-se acrescentar o fato de a desnaturalização da associação automática entre pobreza e criminalidade foi um consenso restrito à universidade, que não se tornou hegemônico na sociedade, aí incluídos jornalistas e policiais. Até porque o contexto imediato atuava em favor da representação pautada pelos indicadores econômicos. O processo de modernização capitalista no país 
criou um parque industrial pujante na economia e uma sociedade complexa e diferenciada, mas as condições para o exercício da cidadania nos anos da redemocratização permanecem tão desiguais quanto a distribuição de renda. Incapaz de prover bens públicos básicos à população pobre, como saneamento, saúde, segurança, educação, o Estado é omisso na prestação de serviços essenciais e não constrói canais institucionais para que parcela expressiva da população encaminhe as suas demandas. Até 2002, haveria a expansão das favelas, que atingem o número de 752 comunidades, abrigando 18,7\% dos moradores da cidade. Cresceria também o medo da violência associada aos moradores das favelas, ao tráfico de drogas e aos conflitos com a polícia, espetacularizados nos jornais.

Nos territórios dominados pelos narcotraficantes, ficou relegada ao passado a imagem romântica e tradicional de que o vazio de poder era ocupado pelo bandido nascido na comunidade ou que com ela mantinha laços clientelistas. No Rio de Janeiro, bandidos organizados empresarialmente e fortemente armados passam a exercer, de forma tirânica, o controle sobre a população nos bairros pobres e nas favelas, valendo-se da difusão do terror (Soares, 2000, p. 29-30). Nesse contexto, a disseminação de outra metáfora, que atribui à cidade ilegal formada pelas favelas a existência de um "estado paralelo", contra o qual a cidade legal deve voltar o seu aparato repressivo, de "guerra". A morte do jornalista Tim Lopes, em 2002, levou o então presidente do Tribunal de Justiça do Estado do Rio de Janeiro, desembargador Marcus Faver, a declarar que o "tribunal do tráfico" havia julgado, condenado e executado o jornalista, amplificando a metáfora do estado paralelo e reforçando a "metáfora da guerra". Enquanto as reflexões dos estudiosos voltavam-se para o provisionamento de bens de cidadania e direitos à população pobre, as imagens consolidadas sobre as favelas estimulavam o medo e o desejo por soluções repressivas e bélicas contra o "estado paralelo" que, por sinédoque 8 , era identificado com toda a favela. Os efeitos colaterais foram a tolerância com a morte de "civis" na guerra (os moradores das favelas) e as restrições ainda maiores a seus direitos. Também o arbítrio policial é incentivado ou tolerado, ofuscando a ideia de uma polícia voltada para a prestação de serviços à cidadania e que atua com base na inteligência e investigação.

A redemocratização já não havia trazido mudanças significativas no arbítrio policial ou no "roteiro

8 As sinédoques são a forma metonímica que toma a "parte pelo todo". Com as antonomásias (tomar o "exemplar pela espécie"), são as formas mais comuns na produção de generalizações e estereótipos, como veremos adiante. típico" da sua atuação repressiva. Sueli Almeida (2000, p. 97-100) mostra que, na década de 1990, policiais civis e militares protagonizaram a violência ordinária "de forma espetacular e midiática" contra as camadas populares, em especial os homens jovens, negros e pobres. Para a autora, os episódios de violência inscrevem-se na lógica da gestão da "questão social", no controle sobre os socialmente excluídos. Paixão (1995, p. 5-7) argumenta que, historicamente, a prática policial é despótica no Brasil independentemente do regime político. A atenção deve ser deslocada do uso da ação policial como instrumento de dominação de classe, para a percepção de que o uso indiscriminado da violência, brutalidade e tortura policial decorrem do fato de a lei não servir de limite à ação policial. Isso aponta para a frágil disseminação, no Brasil, dos princípios universalistas, impessoais e igualitários que regem a vida social no modelo democrático da "ordem sob a lei".

Soares (2000) amplia o diagnóstico para toda a sociedade. A experiência autoritária no regime militar havia ensinado a importância das liberdades clássicas e dos direitos humanos como limites institucionais ao arbítrio do Estado no tratamento dos cidadãos. No entanto, a incapacidade de o Estado prover segurança, garantir a ordem pública e outros bens básicos de cidadania acabaria por legitimar diversas formas de desobediência civil. Os estudos de DaMatta ${ }^{9}$ mostram que, na modernização conservadora, uma característica cultural estabilizada em nossa sociedade seria o híbrido entre relações tradicionais, relacionais e hierárquicas e os princípios igualitários, impessoais e individualistas que regem as sociedades democráticas. Nesse modelo híbrido se assentaria o drama social brasileiro, onde o pior da hierarquia (a naturalização das diferenças entre classes, estamentos e grupos de status e suas consequências como exercício do poder e afirmação da autoridade) mescla-se com um sistema de relações individualistas, estruturado pelo mercado e por princípios universalistas e igualitários de justiça e cidadania, mas gerenciados para legitimar a indiferença e a renúncia pela responsabilidade com o outro (com o álibi de que não se deve ser paternalista no mundo individualista e igualitário). O resultado dessa duplicidade de modelos culturais, da dupla mensagem hierárquico-individualista, seria a flexibilização dos rigores das disciplinas legais e o mecanismo simbólico de naturalização das desigualdades sociais, inclusive a atuação das polícias, que, no contexto da modernização conservadora, sempre foram disciplinadoras e exploradoras dos grupos subalternos.

9 Em especial Carnavais, malandro e heróis - para uma sociologia do dilema brasileiro. Rio de Janeiro: Rocco, 1997. $\sigma^{a}$ edição. 
O que sempre me parece pouco avaliado é a percepção desse dilema cultural brasileiro na operação enunciativa dos jornais. Em minha tese de doutorado ${ }^{10}$, cujo recorte foram as notícias sobre a criminalidade violenta no Rio, mostrei que, como um conta-gotas mental, os jornais repetiam, impunham e consolidavam a interpretação hegemônica da ação policial nos morros da cidade como uma "guerra", quando essa metáfora e a do estado paralelo deixavam de ser empregadas no sentido figurativo para assumir o sentido literal. No processo de selecionar, editar, classificar, opinar, os jornais atribuíam o sentido de capítulos de uma guerra quase perdida pelo Estado (fraco diante do poder bélico dos traficantes) aos violentos confrontos entre policiais e traficantes nas favelas. O resultado imediato seria uma redução da política de segurança à dimensão repressiva, moldando a tolerância da sociedade e dos jornais à morte de "civis", ao desrespeito aos direitos civis e humanos dos moradores de favela e, no plano mais abstrato das estruturas de hegemonia e dominação, a conexão com as práticas históricas de controle sobre os pobres e sua criminalização.

Mas, uma reflexão sobre as heranças e continuidades do período autoritário evidencia ainda que esse comportamento dos jornais assenta-se no mesmo panorama do hibridismo cultural brasileiro. Trata-se da naturalização das desigualdades e da visão hierárquica que lhe é correlata. A exigência, na cobertura dos jornais, de uma atuação policial sob os limites institucionais e da lei não é universal. Quando se tratava da ação policial nas favelas, os princípios hierárquicos sobrepunham-se à defesa do direito à igualdade jurídica (para nos atermos apenas a um direito elementar nas sociedades liberais e democráticas), ou seja, de os moradores das favelas receberem o mesmo tratamento digno e respeitoso que merecem os cidadãos que moram no asfalto. Exemplo recente disso ocorreu na divulgação por O GLOBO da morte de Cláudia Silva Ferreira, vítima de uma operação policial no Morro da Congonha, em Turiaçu, zona norte do Rio. Na edição de 17/03/2014, a morte é anunciada na p. 14, sob a manchete: "Bala perdida mata mulher na zona norte". A nominalização oculta a responsabilidade policial na morte, como já vimos. A narrativa privilegia a voz do comandante do $9^{\circ} \mathrm{BPM}$, que destaca o socorro dos policiais. Em seguida, narra-se o protesto dos moradores que incendeiam dois ônibus. No final (menor importância, segundo a técnica da pirâmide invertida), o lamento do marido da vítima.

No dia seguinte, a operação enunciativa seria de outra proporção. O GLOBO coloca na primeira página a 10 DUARTE, MS, op. cit. dor da família no enterro e destaca uma frase do marido de Cláudia: "Trataram minha mulher como bicho. Nem o pior traficante merece esse tratamento". Um cinegrafista amador havia filmado a cena brutal do corpo de Cláudia sendo arrastado pelo camburão da polícia. A versão de que Claudia havia sido executada também aparece na primeira página. A repercussão das cenas de indiferença e crueldade dos policiais provocou a mudança na avaliação do fato. Apenas no dia 18, a morte de Cláudia é tratada dentro de princípios igualitários e universalistas da proteção à vida e dignidade humanas. $\mathrm{Na}$ edição do dia17, Cláudia é apenas mais uma vítima civil dos confrontos na favela. É interessante perceber ainda que, no dia 18, a notícia possui elementos persuasivos evidentes, com o uso do tratamento emocional e da identificação humana (o personagem como eixo narrativo) para dramatizar o sofrimento da família, o que mostra que o entretenimento pode ter um uso crítico, questão a que voltaremos adiante.

No correto diagnóstico de Rondelli (2000, p. 144), o aumento da violência na década de 1990 foi excessivamente tematizado pelos jornais e pelo debate sobre a natureza e consequências desse crescimento, produzindo o efeito de construir um determinado imaginário sobre a violência. Cruéis, escandalosos e inusitados, esses fatos carregam, portanto, a singularidade atribuída às notícias (ou "os ingredientes para se tornarem fatos jornalísticos”), revelando questão que estão no contexto social imediato: o abandono da infância pobre ou a complexa convivência entre moradores de favelas, traficantes e policiais, por exemplo. A autora destaca ainda a efetiva presença da polícia nos crimes que mais geraram debates. O que é preciso levantar, porém, é que a formatação de um novo gênero ${ }^{11}$ na cobertura jornalística iria se desenvolver. Reformulado ao longo das décadas pós-redemocratização, o gênero da cobertura noticiosa da criminalidade urbana violenta possui o forte traço da mistura de informação, publicidade e entretenimento, que é uma tendência do jornalismo atual, como apontam diversos autores, de Habermas ao próprio Fairclough (1995). "Violência e criminalidade são matérias-primas por seu valor comercial (disputa de audiência, concorrência) e para construir a opinião pública e provocar ações políticas“, escreveu Rondelli (1995, p. 98). Assim, além da espetacularização referida, há um desejo político de intervenção e opinião sobre os desdobramentos dos fatos narrados. Esse desejo está muitas vezes subordina-

11 Fairclough (2003, p. 28) define os gêneros como uma forma de ação, mais exatamente como a forma com que os textos interagem com os eventos sociais. 
do ao enquadramento cultural do dilema cultural brasileiro, em suas hierarquizações culturais e naturalização das desigualdades sociais, o que se apresenta em especial com o tratamento das incursões violentas na favela como evidentemente autojustificadas e necessárias ${ }^{12}$.

\section{A notícia sensacional}

$\mathrm{Na}$ apresentação do livro de Antonio Serra, Muniz Sodré já havia percebido o deslizamento no uso do fait-divers, incorporado pelos jornais classificados de "sérios":

Quando a imprensa dita 'de qualidade' nos fala ou nos mostra, em reportagens, os 'homens de ouro' da polícia em plena sessão de treinamento de combate (judô, tiro ao alvo, etc.), o texto ou as imagens não nos passam pura e neutra informação. Trata-se, antes, de uma operação mítica: a reportagem produz os seus efeitos a partir do fascínio dos crimes que poderão ocorrer e ser combatidos pelos ‘bravos de ouro'. O real é encenado e, por antecipação, resolvido, como na magia. (1980, p. 11)

O conceito de fait-divers não fica restrito a um tipo popular de informação com foco no anômalo e teratológico do fato, usado para narrar a história em função de um espaço fechado sobre si mesmo, intemporal, uma categoria que explicita a dimensão ficcional e folhetinesca dos fatos, operada apenas nos jornais populares (Barthes). Mais que uma simples categoria, o fait-divers é uma grade sistemática de elaboração da notícia, tanto na imprensa "de qualidade" como na "popular". Em todos os jornais impressos, a ficcionalização do fato (e a encenação ou dramatização da vida cotidiana) seria oferecida como mercadoria. O recurso ao entretenimento como elemento persuasivo central do texto informativo tem consequências ideológicas importantes, que deixam marcas nos modos de dizer dos jornais ${ }^{13}$. Sodré (1996) estabelece um nexo causal entre as

12 Devo a Marialva Carlos Barbosa a explicitação desse "desejo de opinião" pelos jornais.

13 No nível ideológico, Fairclough (1995) propõe a distinção entre elementos naturalizados (as ideias, crenças e valores tomados como dados, evidentes e autojustificadas) e persuasivos. A forma narrativa da notícia teatralizada (ou romanesca) e todo um conjunto de elementos próprios à indústria do espetáculo, da publicidade e entretenimento formam um conjunto persuasivo cada vez mais disseminado transformações na forma da notícia, o crescente caráter mercadológico do texto jornalístico e as complexas relações entre novas tecnologias da informação e a atividade jornalística. A informação noticiosa foi descontextualizada e transformada em mercadoria cultural, o que deixaria nítida a penetração do acontecimento sensacional ou insólito (fait-divers) na notícia (geralmente identificado ao universo do jornalismo literário). É possível perceber ainda o arranjo das narrativas dos fatos violentos em conjuntos particulares, nomeados por títulos referenciais como "Guerra do Rio" ou o recente "Obstáculos à Paz” (ambos retirados de O GLOBO), que operam nas transformações dos fatos diários isolados em capítulos de uma mesma história (numa operação por sinédoque), explicitando ainda o "desejo de opinião" do jornal (Marialva Barbosa).

O esforço de consumo da notícia reduziu-se ainda mais com o rádio e a televisão. A rapidez dos meios eletrônicos obrigou o jornal impresso a ampliar o raio informativo da notícia (a passar da descrição do fato para a elaboração de um quadro mais amplo e explicativo do acontecimento). A competição com os meios audiovisuais também transformou o código do jornalismo impresso, que passa a comportar diagramas, recapitulações, quadros e infografia (Sodré, 1996, p.147). Em relação ao texto, as pressões do mercado consumidor o tornam leve e agradável, para que se compatibilize com a atmosfera sedutora do consumo. A dramatização e encenação são revalorizados no ambiente de estímulo ao entretenimento. Entretanto, a nova forma (que altera a news of the day para "show of the day") preserva a pirâmide invertida ${ }^{14}$. A existência deste estilo, agora chamado de "sensacional" (espetáculo), não equivale ao "sensacionalismo". Nasce uma linguagem jornalística que não é a mera verbalização do fato, mas que prioriza o movimento, a descrição cinematográfica, os detalhes e os diálogos. O marco dessas mudanças é o movimento americano chamado New Jornalism, que incorpora também o feature (o texto baseado na "personalização", no "interesse humano") como um reforço das formas literárias tradicionais. Esta narrativa espetacularizada promove um outro tipo de empenho profissional. Ao experimentar novas formas de narração e linguagem, o jornalista troca o empenho da verdade pelo da verossimilhança. Tais modificações são parte de um contexto mais amplo, de encenação pública da vida

nas estratégias de sedução mercadológica da mídia em geral e dos jornais impressos, na busca de consentimento para os significados que veiculam.

$14 \mathrm{O}$ avanço da estrutura de show no jornalismo também analisada em detalhes por Fairclough (1995) e Bourdieu,no ensaio Sobre a televisão. Rio de Janeiro: Zahar, 1997. 
privada, em que a narratividade se impõe como tecnologia cognitiva (Sodré, 1996, p.147:149).

Seja qual for o sentido atribuído à teatralização do texto informativo, a dimensão de espetáculo na prática discursiva jornalística é a forma atual da notícia. O linguista Norman Fairclough (2001, 149-259) descreve o fenômeno como a colonização do gênero jornalístico pelo Marketing, a Publicidade e o entretenimento, combinando informação e persuasão. Contraditório, o sistema permite a emergência de um novo tipo de discurso, constituído especificamente pela "emergência de um discurso híbrido de informação-e-publicidade (ou de "falar-e-vender')". Assim, a nova forma noticiosa torna sem sentido a distinção entre jornais sérios e sensacionalistas, porque a dimensão de entretenimento e o recurso à imagem são, hoje, constitutivos de toda a imprensa, em diferentes graus.

Esse uso do entretenimento como elemento persuasivo potencializa elementos ideológicos naturalizados nos jornais, em especial a proposição de que a metáfora da guerra (tão naturalizada na cultura jornalística e na sociedade civil) passou a ser o modo "natural" de definir a realidade. É o que se vê nessa reportagem de capa publicada por O GLOBO (29/09/2004), com a manchete: "À luz do dia, no Leblon. O que falta mais?" (ver anexo, figura 3). A Análise de discurso não reconhece fronteira entre os níveis descritivo e argumentativo da linguagem. Toda a descrição da realidade é um momento de algum esquema de argumentação e classificação do mundo. E faz isso ao perguntar "de que lugar" (como) esse alguém percebe e interpreta os fatos descritos e a rede de mecanismos discursivos que estruturam o contexto do proferimento. No caso, o fato de o bairro de o Leblon ser alvo de um arrastão é tratado como surpreendente, por ser, afinal, local de policiamento ostensivo. O que se pergunta de imediato é se esse fatos deveriam estar restritos à periferia e áreas menos nobres. Assim, é proposta como natural essa hierarquização da cidade.

Em: "Bela e bandida" (O DIA, primeira página, 15/04/2002, figura 4) ou "Jovem de classe média, estudante de direito e assaltante” (EXTRA, primeira página do mesmo dia), quando os dois jornais espetacularizam a notícia, eles não apenas descrevem, mas atribuem surpresa ao fato de a adolescente presa por roubo não se adequar ao roteiro típico da polícia, explicitando a naturalização das desigualdades. Danilo Marcondes (1992, p. 64) propõe que seria inadequado classificar como apenas "descritivas" as orações da forma "ele fez isto". A principal função destas orações seria atribuir a alguém a responsabilidade de um ato, de determinada ação. As- sim, enunciar: "Tráfico transforma o Rio na Capital do Medo” (JORNAL DO BRASIL, figura 5), não significa descrever meramente a participação do tráfico nos acontecimentos violentos, mas atribuir liderança e responsabilidade aos traficantes nesses episódios. Como assinala Marcondes, trata-se da coexistência de um duplo caráter descritivo-atributivo. As duas categorias não são excludentes e a atribuição de responsabilidade, na maioria dos casos, é a dimensão mais profunda da descrição.

O processo de produção de sentidos depende não apenas do que está explícito num texto, mas também no que está implícito, o "não-dito", que é assumido como verdade inquestionável. Nas reportagens de O DIA e EXTRA, além dos estereótipos sobre o bandido, relação linear entre pobreza e criminalidade é tratada como "evidência"15. Em: "Polícia acha granadas e até minas em arsenal do tráfico" (O GLOBO, figura 6), a manchete vem abaixo do título referencial "Guerra do Rio”. Nesse caso, há subentendidos a serem recuperados com a aplicação das chamadas de leis do discurso, que incluem as máximas conversacionais de Grice. Pela máxima de quantidade (não dê mais ou menos informações do que o contexto requer), pode-se aplicar o princípio "o que vem depois é consequência do que vem antes". Assim, na sequência exposta pelo jornal, a operação policial que encontrou o arsenal do tráfico é um capítulo da guerra travada nos morros. Da mesma forma, as máximas de qualidade (diga sempre a verdade ou o que considera verdadeiro) e relevância (seja relevante) são importantes na análise do uso das metáforas. Os armamentos descritos e destacados "granadas" e "até minas" justifica, pela sua formulação hiperbólica, as operações policiais no morro, inferência tomada a partir do pressuposto do poderio bélico dos traficantes.

O uso das metáforas e metonímias é um aspecto importante na análise de discursos. $\mathrm{Na}$ linha da lingüística cognitiva, entendemos que a metáfora tem uma função compreensiva, enquanto a metonímia fornece um acesso mental ao conceito que se quer compreender. A metáfora usa a similitude entre entidades ou relações sociais distintas para fazer um conceito ser compreendido, como em: "O tribunal do tráfico em ação" (primeira página de $\mathrm{O}$ GLOBO, de 30/04/2008), quando a punição de menores por traficantes é comparada aos ritos de um tribunal. Norman Fairclough (2001, p. 241) mostra que as metáfo-

15 Um aprofundamento sobre a importância das pressuposições e implícitos em relação à ideologia pode ser encontrado em PINTO, Milton José e DUARTE, MS. "Discurso, implícitos e ideologia: 'As ONGs e a visão arcaica da relação entre o público e o estatal”, publicado em: Discursos - coleção de estudos da linguagem como prática social. Rio de Janeiro: Ilustração editora, 2005. 151 
ras estão presentes em todos os tipos de texto, inclusive os científicos e técnicos. Atribuir significados aos objetos e vivências do mundo por meio de uma metáfora e não de outra, é uma forma de construir a realidade de uma maneira e não de outra. Algumas metáforas estariam tão naturalizadas no interior de uma cultura particular "que as pessoas não apenas deixam de percebê-las na maior parte do tempo, como consideram extremamente difícil escapar delas em seus textos, pensamento ou ação, mesmo quando se chama atenção para isto".

Já a metonímia pressupõe uma relação de contiguidade, a existência de duas entidades ou relações que têm uma relação estreita dentro do mesmo espaço conceitual. As interpretações dos textos levam em conta elementos intertextuais para suprir as lacunas. Esses elementos originam-se do senso comum (aquilo que é tomado como dado) e são com freqüência utilizadas na vida cotidiana ou na mídia para forçar generalizações indevidas que levam a uma interpretação tendenciosa (Pinto, 2004). Em: "O Rio está perdendo a guerra contra o tráfico?" (figura 7), a dramatização noticiosa impõe a metáfora como pressuposto (há uma guerra, isso não pode ser negado na resposta) e o emprego das sinédoques obrigam o leitor a compartilhar a noção de que as favelas constituem um território à parte da cidade, cuja ocupação se submete à lógica do apartheid e da guerra, não da cidadania. O leitor é estimulado a dividir os mesmos estereótipos que orientam as redações dos jornais.

Da mesma forma, em: "Tráfico ataca Estado" (figura 8), o Tráfico tomado como o conjunto homogêneo dos traficantes e o Estado, como a organização político-administrativa de um país. A escolha vocabular não é trivial, inocente ou uma simples adequação lógico-semântica ou estética. De forma consciente ou inconsciente, sempre fazemos escolhas entre palavras disponíveis que conformam possibilidades de nomear os objetos do mundo e atribuir sentido a domínios particulares da experiência (Pinto, 2004). Onde existe uma palavra em uso (num contexto de proferimento), portanto, ela nomeia uma prática social. Assim, a repetição de palavras como granadas, minas, ataca, guerra, tráfico etc aponta para um espaço simbólico militarizado, que estrutura a nossa leitura cotidiana da violência no Rio. O uso amplo e abusivo da metáfora da guerra pelos jornais já revela esse consenso social militarizado (Fairclough, 2001). O uso ideológico do entretenimento contribui para afirmar tais preconceitos, ao servir como elemento de persuasão da "guerra" como chave da interpretação da violência no Rio. A análise não se completa, porém, sem observar as estruturas de dominação mais abstratas, as ordens de discurso (elementos linguísticos das redes de práticas sociais). Segundo Foucault, elas podem ser vistas como a organização e controle social das variações linguísticas (portanto, uma forma de tentativa de controle das variações também das práticas sociais). Dessa forma, a construção narrativa da violência reforça a naturalização das desigualdades e das hierarquias que hoje dificultam ações políticas que levem à universalização dos direitos.

É precipitado, no entanto, concluir que o entretenimento é necessariamente acrítico e superficial, porque subsumido à publicidade. Insistir que $\mathrm{O}$ entretenimento não possua funções sociais críticas, significa rejeitar possibilidades, como a tarefa de produzir reportagens de entretenimento que também inclua a informação e o esclarecimento do público, como no caso da morte de Cláudia da Silva Ferreira, narrado por O GLOBO no dia 18.

\section{Referências}

ALMEIDA, Sueli Souza de. "Violência urbana e constituição de sujeitos políticos". RONDELLI et alli (orgs). Linguagens da violência. Rio de Janeiro: Rocco, 2000, p. $97-$ 112.

CARVALHO, Maria Alice Rezende de. "Cidade Escassa e Violência Urbana”. In.: IUPERJ. Violência e participação politica no Rio de Janeiro. Rio de Janeiro, IUPERJ, Série Estudos $n^{\circ} .91$, agosto de 1995.

FAIRCLOUGH, Norman. Analysing discourse - textual analysis for social research. London: Routlege, 2003.

. Discurso e mudança social. Brasília, Editora Universidade de Brasília, 2001.

. Media discourse. London: Arnold, 1995.

LEITE, Marcia Pereira. "Entre o individualismo e a solidariedade: dilemas da política e da cidadania no Rio de Janeiro“. Revista Brasileira de Ciências Sociais, ANPOCS, V. 15, Nº. 44, P. 73-90, outubro, 2000.

MARCONDES, Danilo (1992). Filosofia, linguagem e comunicação. São Paulo: Cortez Editora, 1992.

PAIXÃO, Antônio Luiz. "O 'Problema da Polícia”. In.: IUPERJ. Violência e participação política no Rio de Janeiro. Rio de Janeiro, IUPERJ, Série Estudos nº. 91, agosto de 1995.

PINTO, Milton José. "Discurso e Violência". Revista Virtual Semiosfera: ECO/UFRJ, edição especial, 2003. 
PINTO, Milton José e DUARTE, M. S. "Discurso, implícitos e ideologia". Revista Discursos - estudos da linguagem como prática social. Rio de Janeiro: Ilustração editora, 2005, p. 31-45.

RONDELLI, Elizabeth. "Imagens da violência e práticas discursivas". RONDELLI et alli (orgs). Linguagens da violência. Rio de Janeiro: Rocco, 2000, p. 144-162.

"Mídia, representações sociais da violência, da criminalidade e ações políticas". Comunicação \&Política. Mídia, drogas e criminalidade. Rio de Janeiro: Ed. Cebela. Nova série, v. I, n. 2, dezembro 1994 - março 1995, p. 97-109.

SOARES, Luiz Eduardo. "Uma interpretação do Brasil para contextualizar a violência". RONDELLI et alli (orgs). Linguagens da violência. Rio de Janeiro: Rocco, 2000, p. 23-46.

SODRÉ, Muniz. "Prefácio". In: SERRA, Antonio. O desvio nosso de cada dia: a representação do cotidiano num jornal popular. Rio de Janeiro: Achiamé, 1980.

Reinventando a cultura - a comunicação e seus produtos. Petrópolis: Editora Vozes, 1996.

VALLADARES, Lícia do Prado. A invenção da favela - do mito de origem à favela.com. Rio de Janeiro: Editora FGV, 2005.

Recebido em: 22/01/2015

Aprovado em: 25/03/2015 